\title{
迎角を有する傾斜円柱に作用する風力特性に関する研究 CHARACTERISTICS OF WIND FORCE ACTING ON INCLINED CIRCULAR CYLINDERS WITH YAW ANGLE
}

\author{
片桐純治*, 鶴見俊 雄**, 大熊 武司***, 丸川 比佐夫**** \\ Junji KATAGIRI, Toshio TSURUMI, Takeshi OHKUMA \\ and Hisao MARUKAWA
}

\begin{abstract}
This study investigates the effects of inclination angle and yaw angle for wind forces acting on inclined circular cylinders. In this study, wind forces per unit length acting on the cylinders are measured simultaneously at all positions by using a manifold system. From this study, the following results are obtained;

(1) The modal wind forces acting on the inclined circular cylinders and the Strouhal number are followed to the Cosine Rule or the Independence Principle. Those data are characterized by equivalent yaw angle, which combined with inclination angle and yaw angle. (2) The fluctuating across wind forces transmit from up-stream side to down-stream side in a constant speed. The transmission speed of the fluctuating across wind forces is able to be approximated to a liner function of equivalent yaw angle. (3) The characteristics of wind forces in a uniform flow and a turbulent flow are almost same.
\end{abstract}

Keywords: Inclined circular cylinder, Equivalent yaw angle, Along and across wind force, Cosine rule, Transmission speed 傾斜円柱，等価迎角，風方向及び風直交方向風力，余弦則，伝搬速度

\section{1.はじめに}

鋼管鉄塔では，トラス材である腹材や 2 次部材に極めて細長い部 材が用いられており，このような部材(以下，斜材と称する)の風に よる振動が実鉄塔において観測されている ${ }^{1,2)}$. 鉄塔部材の共振風速 は，部材断面が小さいため設計風速以下になることが多く，比較的 頻繁に渦励振が生じる可能性がある。そのため, 鋼管鉄塔の耐風設 計では暴風時の耐力だけでなく部材に生じる疲労損傷に関する検討 も必要になるものと考えられる. 鋼管鉄塔の斜材の疲労損傷に関す る検討を行う場合，強風の吹く風向が鉄塔の建設される地域や周り の地形に依存するため, 風に対して様々な傾斜角及び迎角について 風応答を求めるための風力特性が必要となる.

傾斜円柱に関する研究は, 鉄塔斜材の他に斜長橋ケーブル, 海洋 構造物等を対象に風洞実験や数值流体解析(CFD)により行われてお $\eta^{33-11)}$ ，傾斜円柱に生じる風力特性が部材軸に直交する風速成分で 特徴付けられる余弦則あるいは Independence Principle と呼ばれる法 則に従うこと ${ }^{3), 4}$, 部材軸に平行に風上から風下に向かう定常的な流 れが傾斜円柱の背面に存在すること 7) 及び傾斜円柱から生じる渦の 構造が直立円柱と異なる組織構造を有すること ${ }^{8}$ 等が明らかにされ ている.しかし，これまでに行われてきた研究の多くが，傾斜円柱 周りの流れの解明やレインバイブレーション, ギャロッピング等の
不安定な振動現象の解明を主な目的としているため, 傾斜円柱の風 応答変位を解析的に求めるための風力特性に関寸る資料は整ってい ない.

著者等は，鋼管鉄塔斜材等の耐風性の検討を目的として，傾斜円 柱に作用する風力分布の特性やこれを用いた風応答予測について検 討を行ってきた ${ }^{12)-14)}$. しかし，これまでの検討は，傾斜角が $45^{\circ}$ 付 近のものに限られていることより，本研究では様々な傾斜角及び迎 角を有する円柱の風力特性について検討を行い，傾斜角及び迎角に よる層風力の部材軸方向分布の特性及び部材全体に作用寸る風力特 性の変化について明らかにする。

\section{2. 実験方法}

実験対象は，直径 $D=10 \mathrm{~cm}$ の円柱であり，図 1 に示すように高さ $1.8 \mathrm{~m}$ の風洞床から天井までの長さの模型を用いた.

実験は，図 2 に示寸傾斜角 $\alpha$ を $45,60,75$ 及び $90^{\circ}$ の 4 種類, 迎角 $\beta$ を $0 ， 10 ， 30 ， 50 ， 70 ， 80$ 及び $90^{\circ}$ の 7 種類としてこれらの 組み合わせについて行った。 なお, 図 2 に示寸 $\beta^{*}$ は風向に対する 傾斜円柱の角度であり，(1)式より求められる. 以下， $\beta^{*}$ を等価迎 角と呼ぶ.

\footnotetext{
本論文の一部は文献16），17）で報告した。

* 陎泉創建エンジニアリング都市環境技術研究所 副所長・博士 (工学

** (株泉創建エンジニアリング都市環境技術研究所 副主任研究員・工修

**** 神奈川大学工学研究所 客員教授・工博

**** 陎泉創建エンジニアリング都市環境技術研究所 所長・博士 (工学)
}

Manager, Urban Environment Research Center, Izumi Sohken Engineering Co., Ltd., Dr. Eng.

Senor Research Engineer, Urban Environment Research Center, Izumi Sohken Engineering Co., Ltd., M. Eng.

Visiting Prof., Institute of Technological Research, Kanagawa University, Dr. Eng.

Director, Urban Environment Research Center, Izumi Sohken Engineering Co., Ltd., Dr. Eng. 


$$
\beta^{*}=\sin ^{-1}(\cos \alpha \cdot \sin \beta)
$$

風圧測定点は，図 1 に示寸ように風洞中心より $1 D$ 間隔に部材軸 と直交する円周上に設けた。測定範囲は, $0.1 \sim 0.9 L$ ( $L$ :模型の長さ) の範囲とし, 傾斜角 $\alpha$ が $45^{\circ}$ では 21 層, $60^{\circ}$ では 18 層, $75^{\circ}$ 及び $90^{\circ}$ では 15 層で測定を行った. 本害験では, 図 1 に示すように部材 軸と直交する 2 方向の風力を測定した。風圧測定点は, マニホール ド 15)を用いて風圧を空間平均することにより層風力の測定を行う ため，図 1 に示す $x$ 方向及び $y$ 方向それぞれの表裏に負担面積が同 じになるように 8 点の風圧測定点を配置した。

風力測定は, 図 3 に示すように $i$ 層の部材軸 2 方向の風力成分 $f_{X}\left(z_{i} ; t\right)$ 及び $f_{Y}\left(z_{i} ; t\right)$ を測定し, これを同一面内の風方向成分 $f_{D}\left(z_{i} ; t\right)$ 及び風直交方向成分 $f_{S}\left(z_{i} ; t\right)$ に変換して解析に用いた. デ ータ測定は, サンプリング間隔 $1 \mathrm{kHz}$, 測定個数 65536 個として, 全 層の風圧を同時測定した.

実験気流は，風洞内に何も置かない状況で得られる気流及び乱流 格子により作成した気流である. 図 4 に実験気流の平均風速及び乱 れ強さの鉛直方向の分布を示寸. 風洞内に何も置かない時の気流は, 床面及び天井面に境界層厚さが約 $20 \mathrm{~cm}$ の乱流境界層が発達してお り, これより内側の気流は乱れ強さが $0.5 \%$ の様流である. 乱流格 子により作成した気流は, 乱れ強さ約 $5 \%$ のほぼ一様な平均風速分 布を有する気流である. 乱れのスケールは $10 \mathrm{~cm} \sim 20 \mathrm{~cm}$ で, 模型直 径の 1 2 倍の值である. 以下, 風洞内に何も置かない状況の気流を 一様流，乱流格子で作成した気流を一様乱流と呼ぶ.

実験ケースは, 一様流中では先に示した傾斜角 $\alpha$ と迎角 $\beta$ の組み 合わせ全てについて行った. 乱流中では, 傾斜角 $\alpha=45^{\circ}$ の迎角 $\beta=0^{\circ} ， 30^{\circ} ， 50^{\circ}$ 及び $90^{\circ}$ について測定を行った.

実験風速 $U$ は, 風洞中央部において約 $11 \mathrm{~m} / \mathrm{s}$ であり, レイノルズ 数 $U D / v(v$ ：動粘性係数 $)$ は約 $8 \times 10^{4}$ である.

\section{3. 実験結果及び考察}

\section{1 層風力特性}

最初に, マニホールドを用いることの妥当性について検討した結

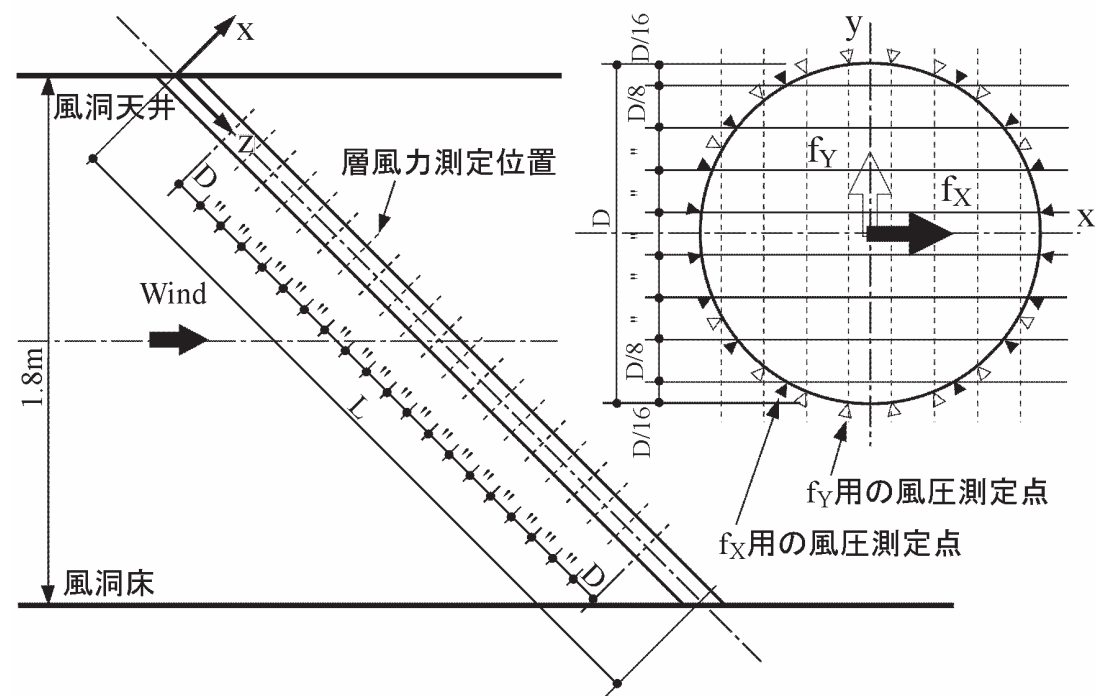

図 1 実験模型の設置状況及び風圧測定点の配置
果について示す. 図 5 に $\alpha=45^{\circ}$ の模型中央部を対象として全点同 時測定した風圧及びマニホールドにより測定した $X$ 方向及び $Y$ 方 向の層風力より(2), (3)式より求めた層風力係数の比較を示す. 平均 層風力係数及び変動風力係数はいずれも一致した結果が得られてい る.また，図には示していないが，パワースペクトル密度も一致し た結果が得られた。これより，マニホールドを用いた測定が妥当な ものと考えられる.

$$
C_{f X}=\frac{\bar{f}_{X}}{q D}, C_{f Y}=\frac{\bar{f}_{Y}}{q D}
$$

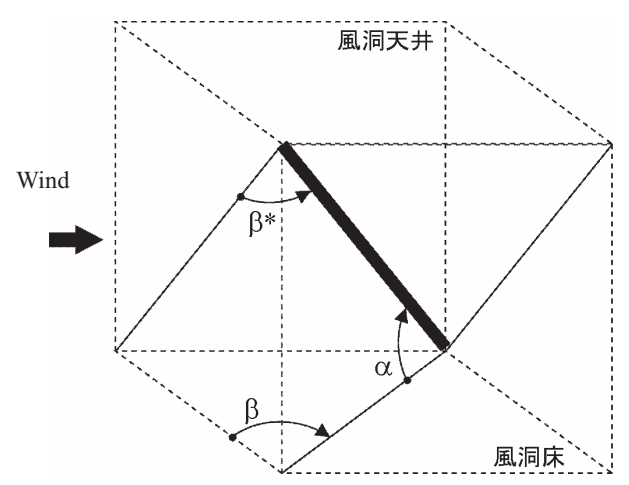

図 2 傾斜角 $\alpha$, 迎角 $\beta$ 及び等価迎角 $\beta^{*}$ の定義

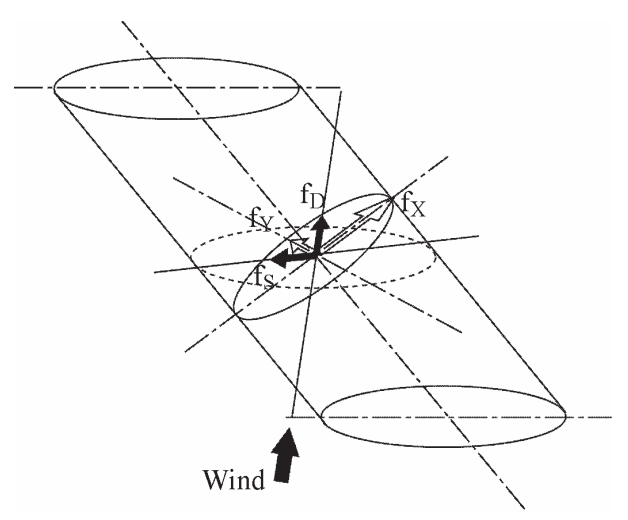

図 3 層風力の定義

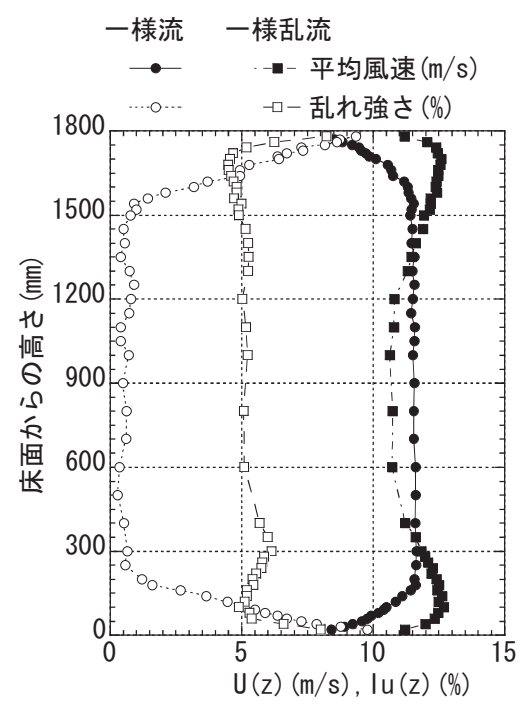

図 4 実験気流 


$$
C_{f X}^{\prime}=\frac{\sigma_{f X}}{q D}, C_{f Y}^{\prime}=\frac{\sigma_{f Y}}{q D}
$$

ここで, $\bar{f}_{X}, \bar{f}_{Y}$ : 模型中央部の $X$ 方向及び $Y$ 方向の単位長さ当たり の平均層風力, $\sigma_{f X}, \sigma_{f Y}$ : 模型中央部の $X$ 方向及び $Y$ 方向の単位長さ 当たりの変動層風力の標準偏差, $q$ : 速度圧 $\left(=1 / 2 \rho U^{2}\right), \rho$ : 空気密度 である。

\subsection{1 平均層風力の部材軸方向分布}

図 6 に(4)式より求めた平均層風力係数の一例として, $\alpha=45^{\circ}$, $\beta=90^{\circ}$ 及び $50^{\circ}\left(\beta^{*}=45^{\circ}\right.$ 及び $\left.32.8^{\circ}\right)$ と $\alpha=60^{\circ}, \beta=90^{\circ}$ $\left(\beta^{*}=30^{\circ}\right)$ の平均層風力係数の部材軸方向分布を示寸. ここで, $\bar{f}_{D}(z), \bar{f}_{S}(z)$ ：風方向及び風直交方向の単位長さ当たりの平均層風 力, $z$ : 天井側の模型端部からの軸方向の座標である.

$$
C_{f D}(z)=\frac{\bar{f}_{D}(z)}{q D}, C_{f S}(z)=\frac{\bar{f}_{S}(z)}{q D}
$$

一様流中の風方向平均層風力係数は, 傾斜角 $\alpha$ 及び迎角 $\beta$ に関わ らず風上側端部付近において大きく, 風下側端部付近において小さ くなる傾向がある，風直交方向平均層風力は，左右対称な円柱であ るにもかかわらず生じており, 風上側より風下側に向かって指数的 に減少しながら正弦波的に増減している.

一様乱流中では, 一様流に比べ下流側（床付近）の風方向平均層風 力係数が大きい. 風直交方向平均層風力係数の分布は, $\beta^{*}=32^{\circ}$ の 風下側(床側)を除き一様流中と同様に, 風上側より風下側に向かっ

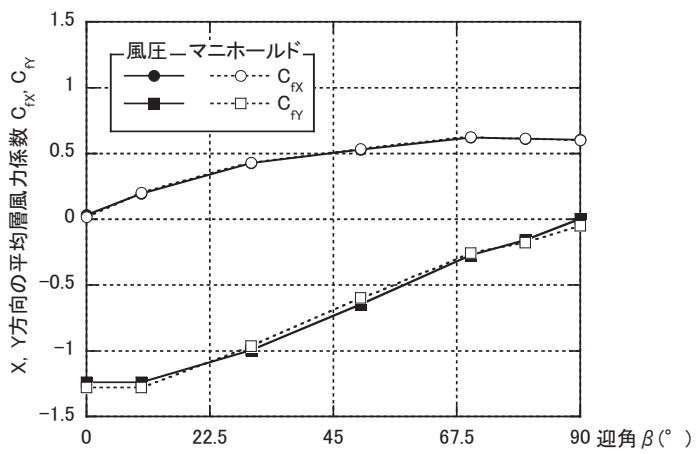

(a) 平均層風力係数

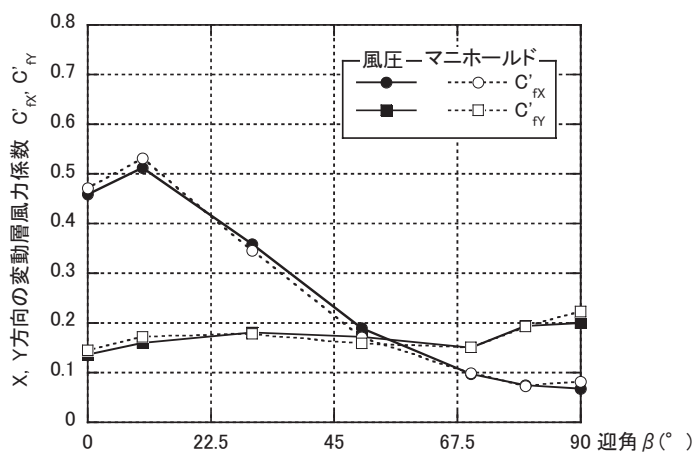

(b) 変動層風力係数

図 5 部材中央部における $X$ 方向及び $Y$ 方向層風力係数の 風向変化 (一様流, $\alpha=45^{\circ}$ )
て指数的に減少しながら正弦波的に増減している.

\section{1 .2 風直交方向変動層風カのパワースペクトル密度}

図 7 に風直交方向の変動層風力の基準化パワースペクトル密度の 一例として, 先に示した平均層風力係数の場合と同様の傾斜角 $\alpha$ 及 び迎角 $\beta$ について示す．ここで, $S_{F S}\left(z_{i} ; n\right): i$ 層の風直交方向変動 層風力のパワースペクトル密度, $n$ ：周波数である.

一様流中の $\alpha=45^{\circ}, \beta=90^{\circ}\left(\beta^{*}=45^{\circ}\right)$ 及び $\alpha=60^{\circ}, \beta=90^{\circ}$ $\left(\beta^{*}=30^{\circ}\right)$ の場合のパワースペクトル密度は, 風上部分では低周波 数側の変動成分が大きく，風下になるほどピーク周波数以下の低周 波数成分のパワーが減少し，中央部付近より風下ではほぼ同様のス ペクトル形状となる。傾斜角の違いによるスペクトル形状の変化を 見ると、ピーク形状が明瞭な風下部分では傾斜角が大きいほど鋭く なる。等価迎角 $\beta^{*}$ がほぼ同じ $\alpha=45^{\circ}, \beta=50^{\circ} \quad\left(\beta^{*}=32.8^{\circ}\right)$ と $\alpha=60^{\circ}, \beta=90^{\circ}\left(\beta^{*}=30^{\circ}\right)$ のパワースペクトル密度を比較すると, $z / L$ が 0.25 以下の風上部分を除きピーク周波数及びスペクトル形 状はほぼ同じである。

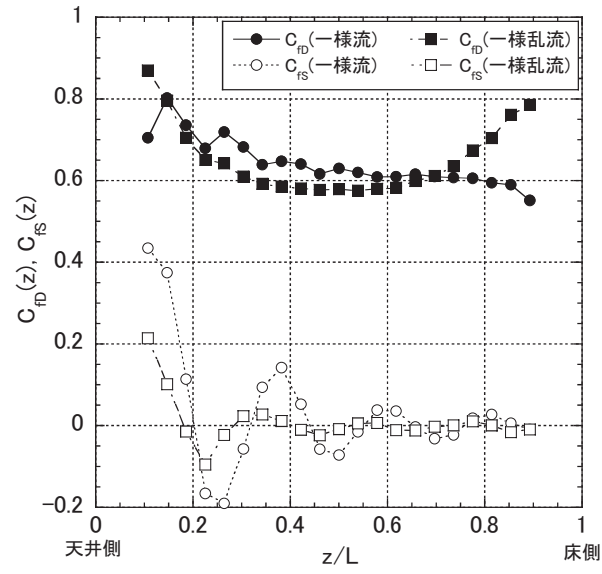

(a) $\alpha=45^{\circ}, \quad \beta=90^{\circ}, \beta^{*}=45^{\circ}$

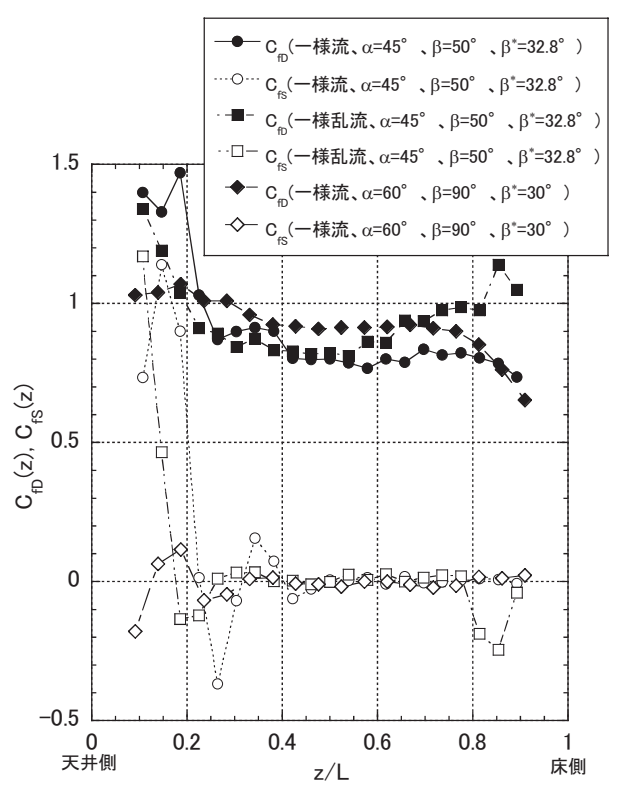

(b) $\beta^{*}=30^{\circ}$ 付近

図 6 平均層風力係数分布 
$\beta^{*}=45^{\circ}$ の一様乱流中の風直交方向層風力のパワースペクトル密 度は, $z / L=0.34$ より風下では一様流中と同様のスペクトル形状で ある。

\section{2 一般化風力特性}

部材全体に作用する風力特性の検討を行うため, 両端がピン支持 された部材を想定して，(5)式に示す振動モード $\mu(z)$ を仮定し (6)式 より一般化風力 $F(t)$ を求めた.ここで, $f\left(z_{i} ; t\right): i$ 層の層風力, $L$ : 部 材長さ, $\Delta z_{i}$ : 負担長さである.

$$
\begin{aligned}
& \mu(z)=\sin (\pi z / L) \\
& F(t)=\sum_{i=1}^{n} \mu\left(z_{i}\right) f\left(z_{i} ; t\right) \Delta z_{i}
\end{aligned}
$$

\subsection{1一般化風力係数}

図 8 に(7)式より求めた風方向一般化平均風力係数 $C_{F D}$ の等価迎角

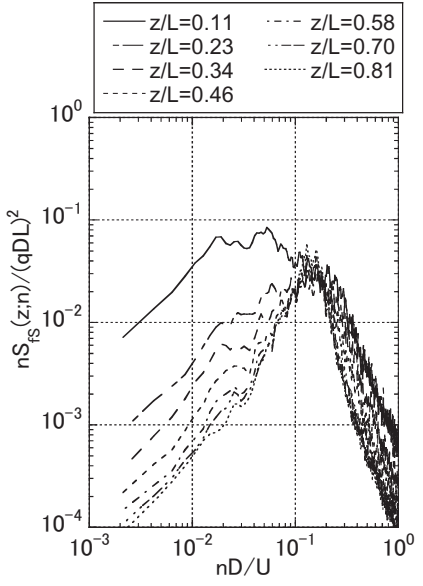

(i) 一様流

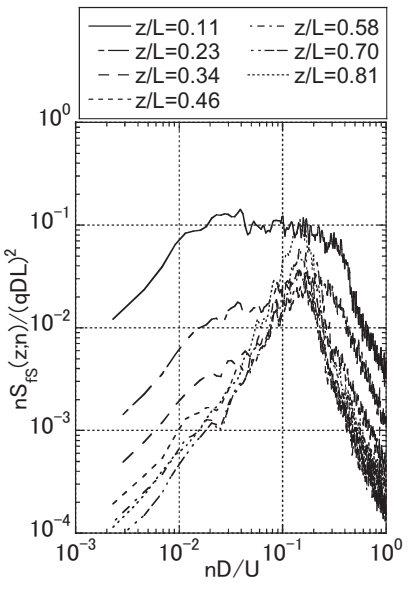

(ii) 一様乱流

(a) $\alpha=45^{\circ}, \quad \beta=90^{\circ}, \beta^{*}=45^{\circ}$

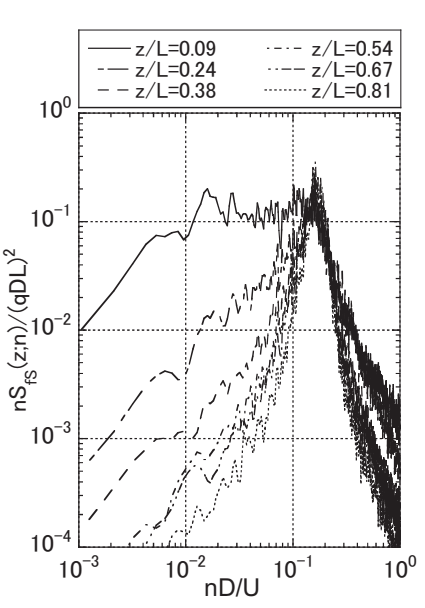

(i) $\alpha=60^{\circ}, \beta=90^{\circ}$ $\beta^{*}=30^{\circ}$

(b) $\beta^{*}=30^{\circ}$ 付近, 一様流

図 7 風直交方向変動層風力のパワースペクトル密度 $\beta^{*}$ による変化を示す.ここで, $\bar{F}_{D}$ ：風方向一般化平均風力である.

$$
C_{F D}=\frac{\bar{F}_{D}}{q D L}
$$

風方向一般化平均風力係数 $C_{F D}$ は, 傾斜角及び迎角によらず等価 迎角 $\beta^{*}$ に対して同じ傾向を示している.傾斜円柱の風方向一般化平 均風力係数 $C_{F D}$ は部材軸に直交する風速成分で特徵付けられるこ とが既往の研究 ${ }^{4)}$ に示されているが, 本実験結果も図中に示した $\cos ^{2} \beta^{*}$ の曲線と良く一致している. 一様流と一様乱流での $C_{F D}$ の結 果は同様であり，気流による差は見られない。

図 9 に(8)式より求めた風直交方向一般化変動風力倸数 $C_{F S}^{\prime}$ を示す. ここで， $\sigma_{F S}$ : 風直交方向一般化風力の標準偏差である.

$$
C_{F S}^{\prime}=\frac{\sigma_{F S}}{q D L}
$$

風直交方向一般化変動風力係数 $C_{F S}^{\prime}$ は, $C_{F D}$ に比べてばらつきが 大きいものの, $C_{F D}$ と同様に $\beta^{*}$ による変化は $\cos ^{2} \beta^{*}$ の曲線でほぼ 表すことができる，気流による差は， $\beta^{*}$ が $30^{\circ}$ 以上では見られな いが, $\beta^{*}$ が $20^{\circ}$ 以下では一様乱流中の方がやや大きくなっている.

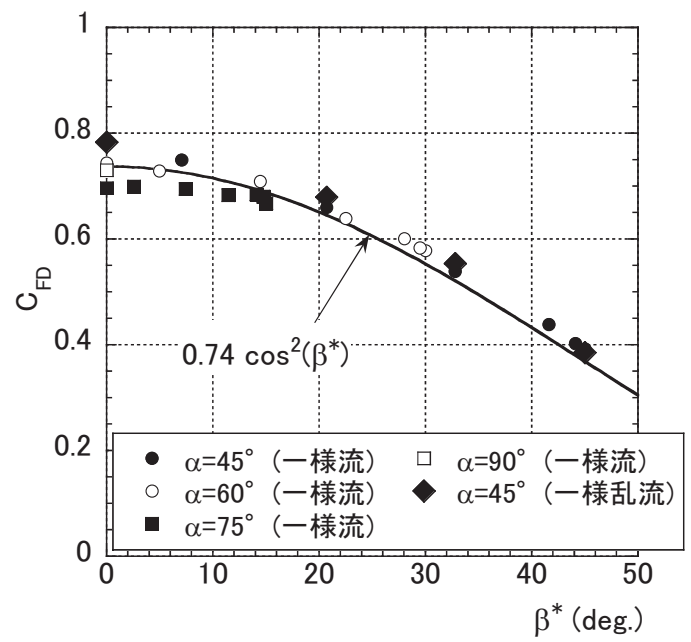

図 8 風方向一般化平均風力係数

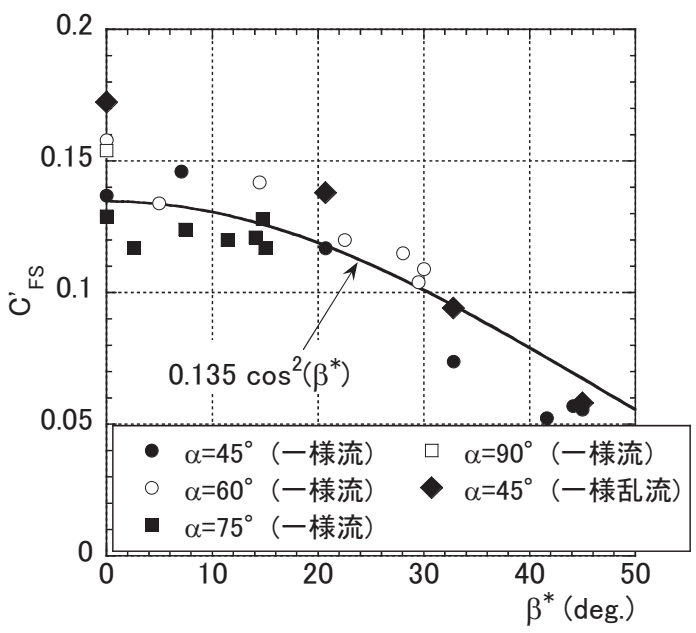

図 9 風直交方向一般化変動風力係数 


\subsection{2 風直交方向一般化風カのパワースペクトル密度}

図 10 に風直交方向の一般化風力の基準化パワースペクトル密度 の一例を示寸.ここで, $S_{F S}(n)$ : 風直交方向の一般化風力のパワー スペクトル密度である。

風直交方向の一般化風力のパワースペクトル密度は, 傾斜角 $\alpha$ 及 び迎角 $\beta$ によらず図 7 に示した層風力に比べてピークが鋭く, 渦に よる明瞭なピークを有している.

$\beta=90^{\circ}$ の場合の傾斜角 $\alpha$ によパワースペクトル密度の変化(図 $10(\mathrm{a})$ )を見ると， $\alpha$ の増加に伴ってピーク周波数は高くなり，スペク トルのバンド幅は狭くなっている. $\alpha=45^{\circ}$ の場合の迎角 $\beta$ による パワースペクトル密度の変化(図 10(b)) は, 傾斜角 $\alpha$ の場合と逆に迎 角 $\beta$ の減少に伴ってピーク周波数は高くなり, スペクトルのバンド 幅は狭くなる.これらの結果を $\beta^{*}$ の変化で見た場合, いずれも $\beta^{*}$ の 増加に伴ってピーク周波数は低くなり,バンド幅は広くなっている. 気流による風直交方向の一般化風力のパワースペクトル密度の変

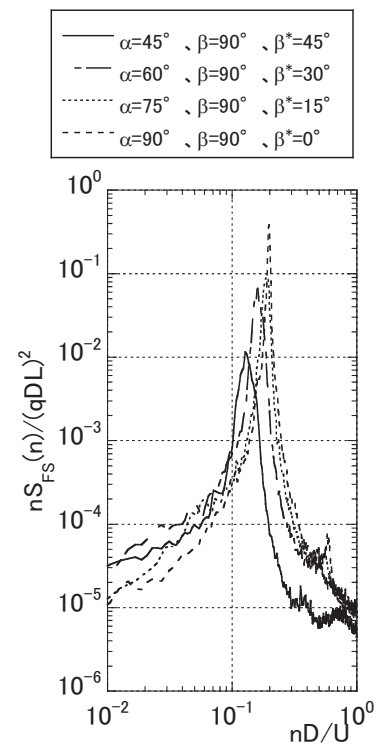

(a) 傾斜角による変化 (一様流)

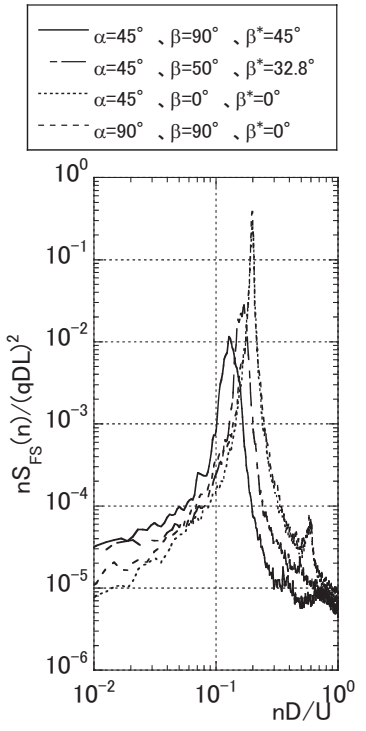

(b) 迎角による変化 (一様流)

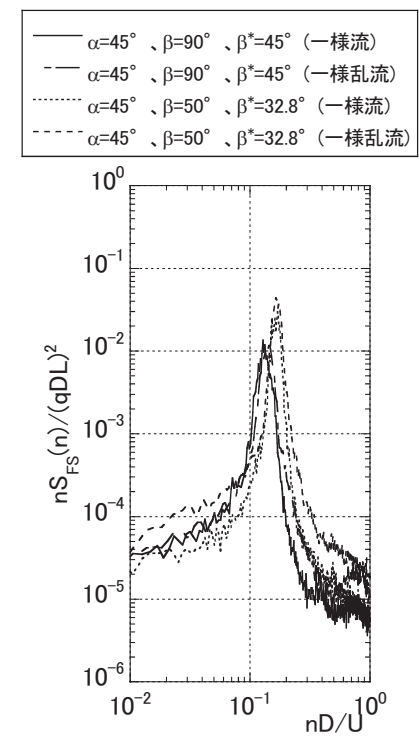

(c) 気流による変化

図 10 風直交方向一般化風力のパワースペクトル密度

化(図 10(c)) は, スペクトルの高周波数側の裙部分にやや差が見られ るもののピーク周波数及びピーク形状の気流による差は小さい.

図 11 に風直交方向の一般化風力のパワースペクトル密度 $S_{F S}(n)$ がピーク值の半分の值となる位置における中心周波数 $n_{S}$ より(9)式 で求めたストローハル数 $S_{t}$ 及び $n_{S}$ におけるピークの幅 $\Delta n$ より (10) 式で求めたスペクトルピークのバンド幅 $B$ の等価迎角 $\beta^{*}$ による変 化を示す.

$$
\begin{aligned}
& S_{t}=n_{S} D / U \\
& B=\Delta n D / U
\end{aligned}
$$

ストローハル数 $S_{t}$ は, 傾斜角 $\alpha$ 及び迎角 $\beta$ によらず $\cos \beta^{*}$ の関数 として表すことができ，一般化風力係数と同様に部材軸に直交する 風速成分で特徵付けられる. また, 気流による変化は一般化平均風 力係数と同様に小さい.

バンド幅 $B$ は， $S_{t}$ に比べてばらついているものの等価迎角 $\beta^{*}$ の 一次関数で表すことができる。

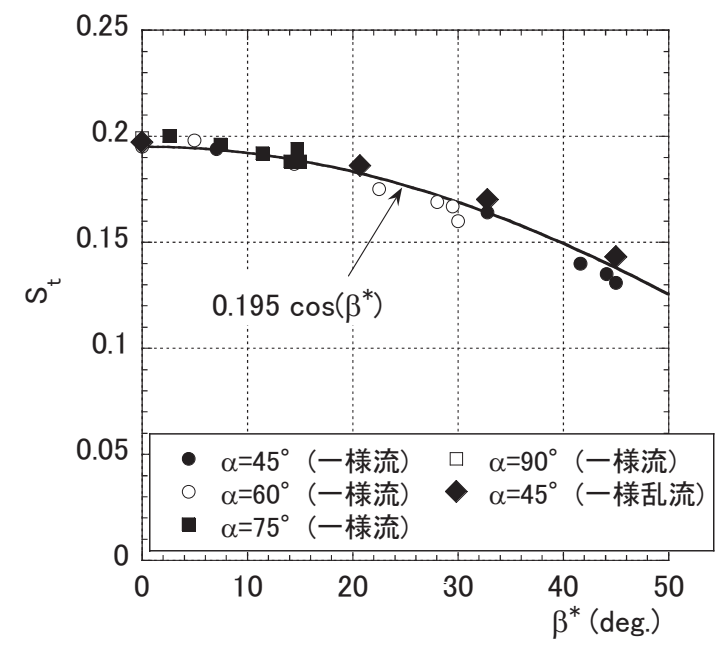

(a) ストローハル数

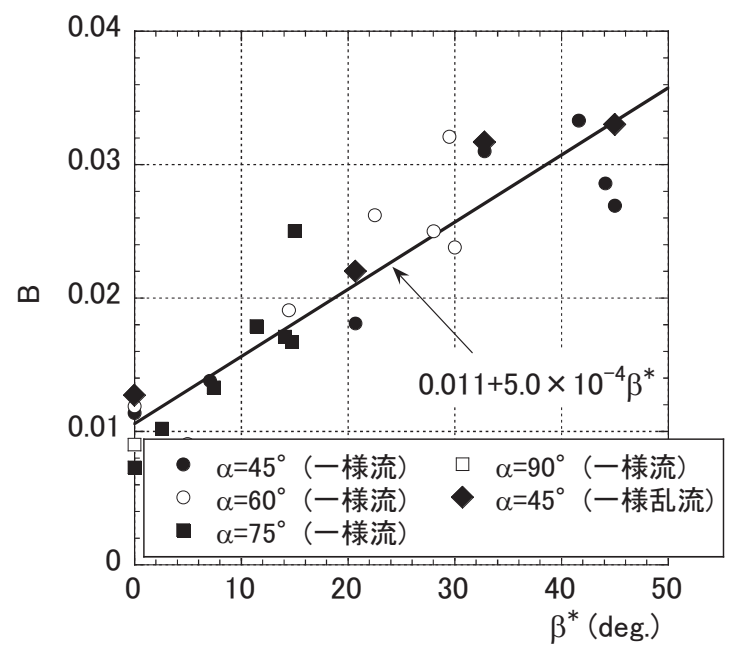

(b) バンド幅

図 11 風直交方向一般化風力のストローハル数 $S_{t}$ 及びパワースペクトル密度のバンド幅 $B$ 


\section{3 風直交方向層風力の部材軸方向相関特性}

\subsection{1 位相差及び風直交方向変動風力の伝搬速度}

図 12 に部材中央部と各層の風直交方向変動風力の位相差 $\theta(n)$ の 一例として, $\alpha=45^{\circ}, \beta=90^{\circ}$ の結果を示寸. 図 12 は横軸の周波 数を直径と風速で基準化した $n D / U$ とした場合と, 層間距離 $\Delta z$ と風 速で基準化した $n \Delta z / U$ とした場合について示した.

横軸を $n D / U$ とした場合の図には一般化風力のパワースペクト ル密度を示したが, 全ての層の位相差が一般化風力のパワースペク トル密度のピーク周波数とほぼ同じ周波数で 0 となっており, 傾斜 円柱全体にわたって同時に渦が放出されていることが分かる.また, 横軸を $n \Delta z / U$ とした場合, 位相差の傾きは全ての層で同じであり， 風力変動が傾斜円柱全体にわたって一様な速度で伝搬していること が分かる. なお, 図 12 の例では, 図に示した周波数全体にわたって 位相差は直線的に変化しているが, 等価迎角 $\beta^{*}$ が小さい場合は位 相差が直線的に変化する周波数範囲は一般化風力のピーク周波数付 近に限定されている.

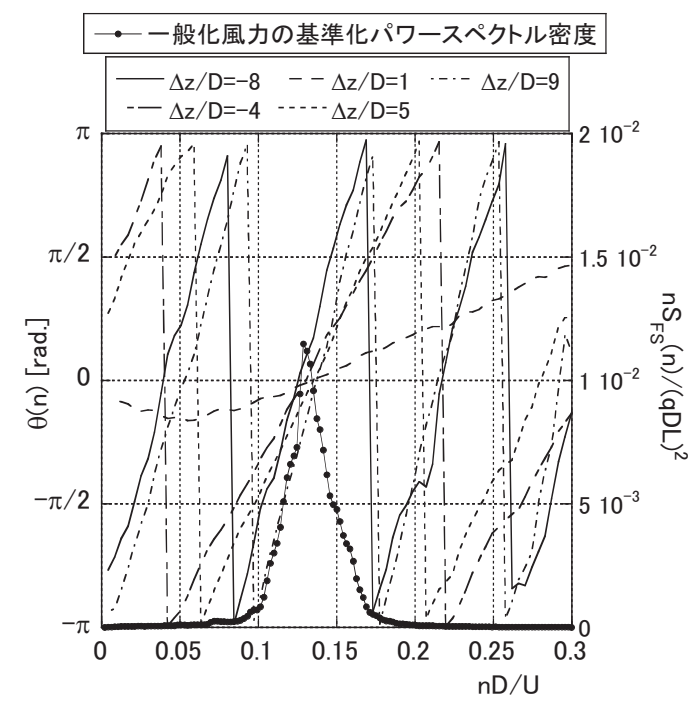

（a）横軸の周波数を直径 $D$ で基準化した場合

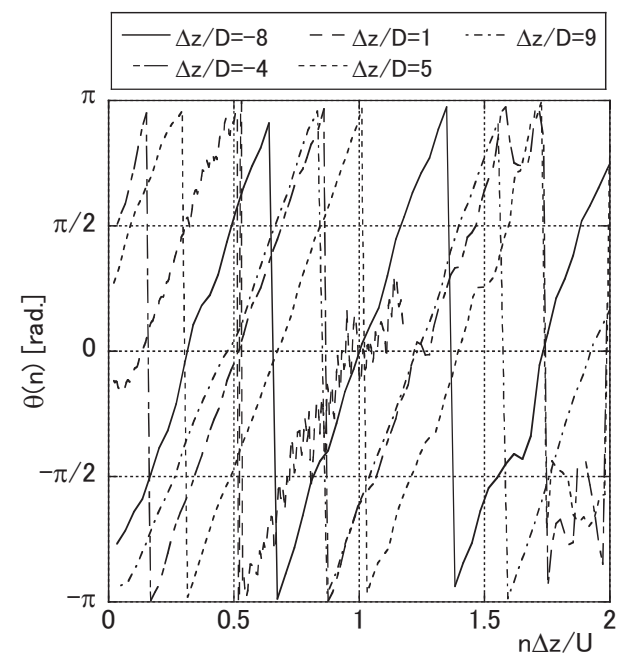

(b) 横軸の周波数を層間距離 $\Delta z$ で基準化した場合

図 12 風直交方向層風力の位相差

$\left(\alpha=45^{\circ}, \beta=90^{\circ}, \beta^{*}=45^{\circ}\right.$, 一様流 $)$
横軸を $n \Delta z / U$ とした場合の位相差の傾きより求めた風直交方向 変動風力の伝搬速度 $U_{C}$ と風速 $U$ の比 $U_{C} / U$ の等価迎角 $\beta^{*}$ による 変化を図 13 に示す. なお, 伝搬速度比 $U_{C} / U$ は位相差 $\theta(n)$ が(11) 式で近似できる場合，(12)式より求められる，ここで，aは位相差 の勾配を表す定数である.

$$
\begin{aligned}
& \theta(n)=a \cdot n \Delta z / U \\
& U_{C} / U=2 \pi / a
\end{aligned}
$$

伝搬速度比 $U_{C} / U$ は, $\beta^{*}=7 \sim 45^{\circ}$ の範囲では $\beta^{*}$ の一次関数で表 される。 また, 気流による $U_{C} / U$ の変化は小さい.

Yeo et al..$^{9}$ は風直交方向風力の $U_{C} / U$ を $\mathrm{CFD}$ の解析結果より求め ており, Yeo et al. ${ }^{9}$ による $U_{C} / U$ と図 13 に示した近似式より求めた $U_{C} / U$ との比較を表 1 に示した。本実験結果より求めた $U_{C} / U$ は, Yeo et al. ${ }^{9}$ によるものより若干大きめではあるが, ほぼ一致した結果 が得られている. なお，両者の差は Yeo et al. ${ }^{9)}$ が端部条件として周 期境界条件を用いた解析を行っており，本実験と端部条件が違うこ とにより生じた可能性が考えられる.

図 14 に風直交方向層風力の時系列波形を示寸。図 14 の時系列波 形は, 横軸に測定した時刻を用いた場合と, 図 10 の伝搬速度より(13) 式により得られる時間遅れ $t_{d}$ を差し引いた時刻を用いた場合につ いて示した. なお, 図 14 に示した $z / L=0.50$ 及び 0.62 は, $z / L=0.38$ よりそれぞれ $3 D$ 及び $6 D$ 離れた位置にある.

$$
t_{d}=\Delta z / U_{C}
$$

$S_{t}$ と $U_{C} / U$ を用いて(14)式より渦放出の 1 周期の間に風力変動が 伝搬する距離 $z_{S}$ が求められるが, $z / L=0.38$ から見て $z / L=0.50$ は 渦放出の半周期の間に伝搬する距離にほぼ対応し, $z / L=0.62$ は渦 放出の一周期の間に伝搬する距離にほぼ対応する。そのため, 図

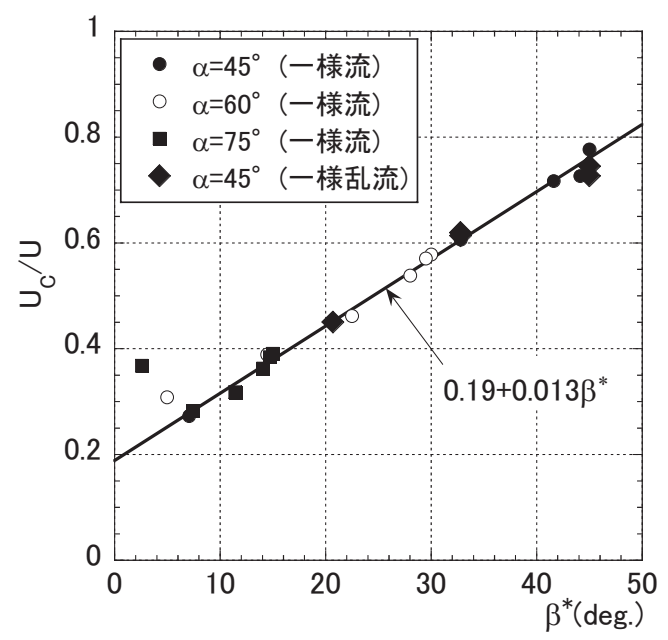

図 13 風直交方向風力の部材軸方向の伝搬速度 $U_{C} / U$

表 1 Yeo et. al. ${ }^{99}$ における

風直交方向風力の伝搬速度比 $U_{C} / U$ と本実験結果の比較

\begin{tabular}{|c|c|c|}
\hline$\beta^{*}$ & Yeo et. al. ${ }^{9)}$ & $\begin{array}{c}\text { 本実験結果 } \\
\text { (図 13 の近似式より) }\end{array}$ \\
\hline 20.7 & 0.330 & 0.45 \\
\hline
\end{tabular}


14(b)の $z / L=0.50$ における風力は符号を逆転して示している.

$$
\frac{z_{S}}{D}=\frac{U_{C}}{U} \frac{1}{S_{t}}
$$

図 14(a)の測定時刻を横軸とした時系列波形は, ほぼ同じ周期で変 動しているが，各層の波形は一致していない。一方，伝搬速度より 得られる時間差 $t_{d}$ を考慮した時系列波形は, $z / L=0.38$ から見て $z / L=0.50$ と $z / L=0.62$ では距離がそれぞれ $3 D$ 及び $6 D$ 離れている にも関わらずよく一致している.これからも風直交方向の風力変動 が一定速度で部材軸方向に伝搬することが確認された。

困 15 に(14)式より求まる渦放出 1 周期の間に伝搬する距離 $z_{S} / D$ と図 6 の風直交方向平均層風力係数がゼロクロスする間隔より求め た部材方向の平均層風力係数の周期 $z_{C} / D\left(z_{C}\right.$ : 風直交方向平均層 風力係数が 1 周期する距離)の比較を示す.なお, 図 15 は風直交方 向平均層風力係数に周期性の見られた等価迎角 $\beta^{*}=20^{\circ}$ 以上につい て示した. $z_{C} / D$ と $z_{S} / D$ の関係はほぼ線形で表わされ, 風直交方 向の平均層風力と風直交層風力の部材方向の伝搬には関連性がある ことが示された。

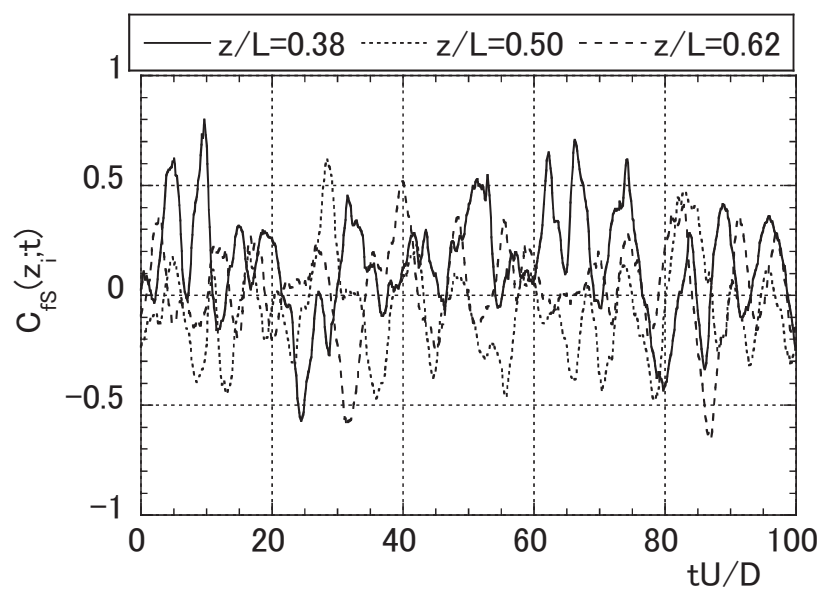

(a) 横軸を測定時刻 $t$ とした場合

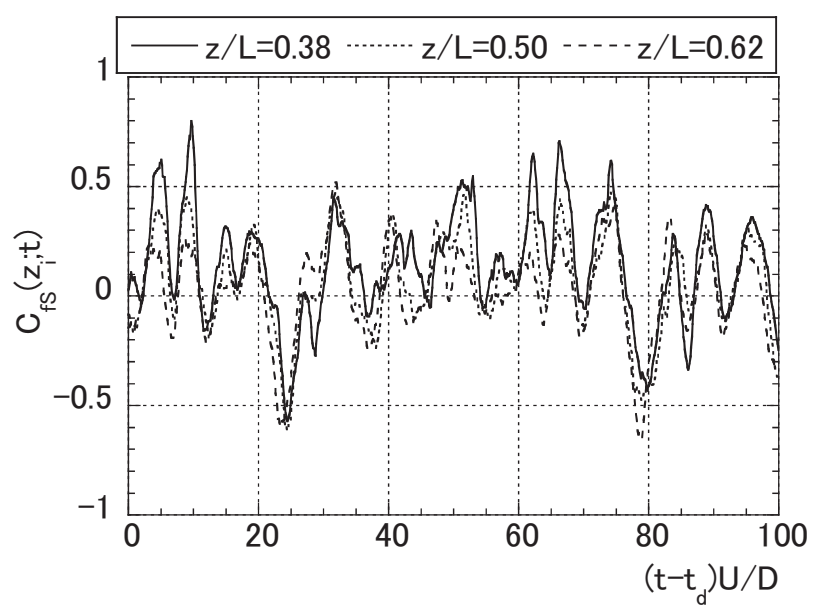

(b) 横軸を測定時刻 $t$ 一時間差 $t_{d}$ とした場合 （z/L=0.5の波形は符号を逆転して示している。）

図 14 風直交方向層風力の時系列波形

$\left(\alpha=45^{\circ}, \beta=90^{\circ}, \beta^{*}=45^{\circ}\right.$, 一様流 $)$
なお，傾斜角 $38^{\circ}$ の飛翔体の可視化実験 ${ }^{8)}$ では，円柱後流に非対 称渦が形成されることが示されており，本実験における傾斜円柱に おいても非対称渦が形成されるために風直交方向の平均層風力が生 じたものと推測される。これに関しては今後可視化実験等により検 討していく必要がある.

\subsection{2 ココヒーレンス}

図 16 に(15)式より求まる部材中央部と各層の風直交方向変動風力 のココヒーレンス $\gamma_{i j}(n)$ の一例として, 一様流における $\alpha=45^{\circ}$, $\beta=90^{\circ} \quad\left(\beta^{*}=45^{\circ}\right), \alpha=45^{\circ}, \beta=50^{\circ} \quad\left(\beta^{*}=32.8^{\circ}\right)$ 及び $\alpha=45^{\circ}$, $\beta=10^{\circ}\left(\beta^{*}=7^{\circ}\right)$ の結果を示す. 図 16 は横軸を(16)式より得られる $\tilde{n}$ としている. ここで, $S_{f S}\left(z_{i}, z_{j} ; n\right): i$ 層と $j$ 層の風直交方向風力の クロススペクトル密度, $S_{f S}\left(z_{i} ; n\right): i$ 層のパワースペクトル密度, $\operatorname{Re}[]$ : クロススペクトル密度の実数部, $n_{S}$ :一般化風力のパワース ペクトル密度のピークの中心周波数, $\Delta z$ 層間距離である.

$$
\begin{aligned}
& \gamma_{i j}(n)=\frac{\operatorname{Re}\left[S_{f S}\left(z_{i}, z_{j} ; n\right)\right]}{\sqrt{S_{f S}\left(z_{i} ; n\right) S_{f S}\left(z_{j} ; n\right)}} \\
& \tilde{n}=\left(n-n_{S}\right) \Delta z / U
\end{aligned}
$$

ココヒーレンス $\gamma_{i j}(n)$ は, 等価迎角 $\beta^{*}=45^{\circ}$ の場合, 一般化風力 のパワースペクトル密度と一致する周波数において層間距離にかか わらず高い相関を示しており，ピーク周波数から離れるに従って $\gamma_{i j}(n)$ は減少し $\tilde{n}= \pm 0.3$ 前後において高い負相関を示している. $\gamma_{i j}(n)$ の負側のピーク值は, $\beta^{*}$ の増加に伴って減少し, $\beta^{*}$ が $15^{\circ}$ 付近より小さくなると負側のピークは明瞭ではなくなる。また, $\tilde{n}=0$ 付近の $\gamma_{i j}(n)$ は $\beta^{*}$ が $15^{\circ}$ 付近より大きい場合は層間距離 $\Delta z / D$ にかかわらず 1 付近の值を示すが， $\beta^{*}$ が $15^{\circ}$ 付近より小さく なると層間距離が大きくなるほど減少する.

ココヒーレンスの特性より, 図 7 の層風力と図 10 の一般化風力の パワースペクトル密度の形状の差は, 風直交方向層風力の部材軸方 向の相関特性によるものであることが分かる.

図 16 には， $\gamma_{i j}(n)$ を(17)式で近似した結果を示したが，実験值と ほぼ一致している。ここで伝搬速度比 $U_{C} / U$ は図 13 の近似式より 求めた值とした.

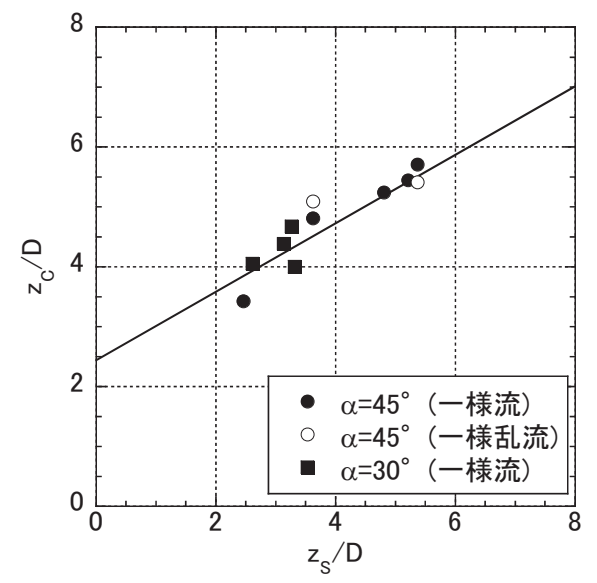

図 15 渦放出 1 周期の間の伝搬距離 $z_{S} / D$ と 風直交方向平均風力係数の部材方向の周期 $z_{C} / D$ の関係 


$$
\gamma_{i j}(n)=\exp (-k|\tilde{n}|) \cos \left(\frac{2 \pi \tilde{n}}{U_{C} / U}\right)
$$

図 17 に(17)式中のココヒーレンスの減衰係数 $k$ の等価迎角 $\beta^{*}$ に よる変化を示す. 図 17 は $\beta^{*}$ が約 $15^{\circ}$ 以上の場合について示した.

$k$ は一様流に比べて一様乱流では大きめの值を示すが，いずれの 気流中も $\beta^{*}$ の増加に伴って単調に減少する. 図には一様流での結果 を関数近似した曲線を示しているが, 減衰係数 $k$ も等価迎角 $\beta^{*}$ の関 数として表すことが出来る.

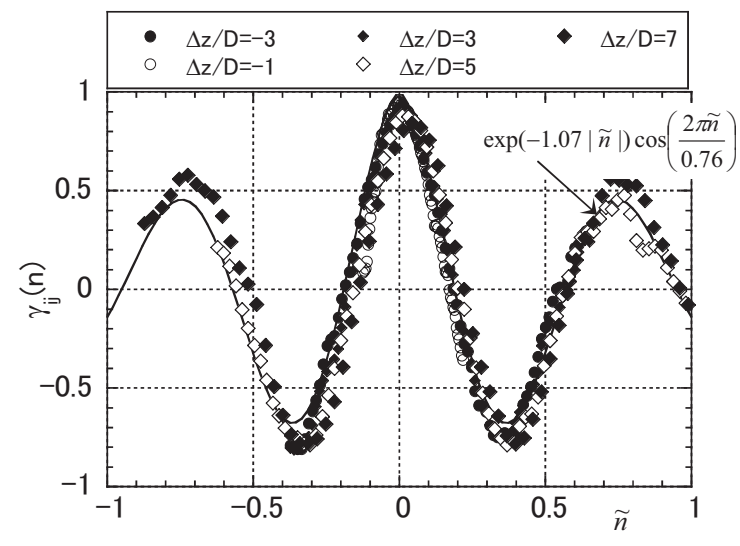

(i) $\alpha=45^{\circ}, \beta=90^{\circ}, \beta^{*}=45^{\circ}$

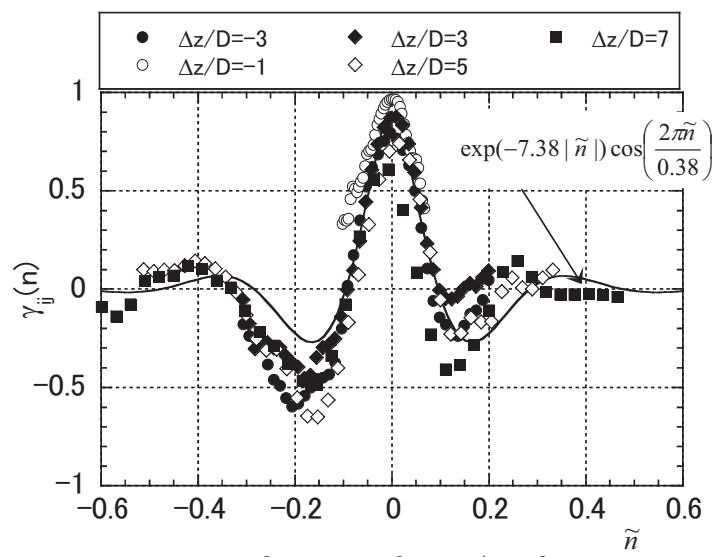

(ii) $\alpha=75^{\circ}, \beta=90^{\circ}, \beta^{*}=15^{\circ}$

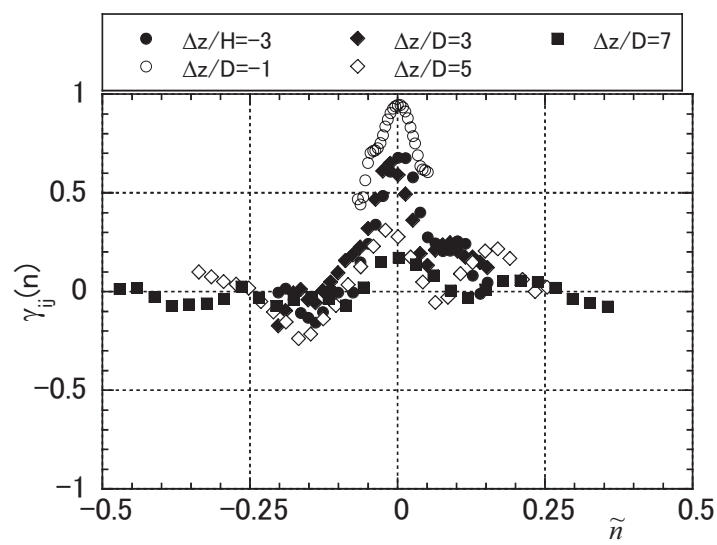

(iii) $\alpha=45^{\circ}, \beta=10^{\circ}, \beta^{*}=7^{\circ}$

図 16 風直交方向層風力のココヒーレンス (一様流)

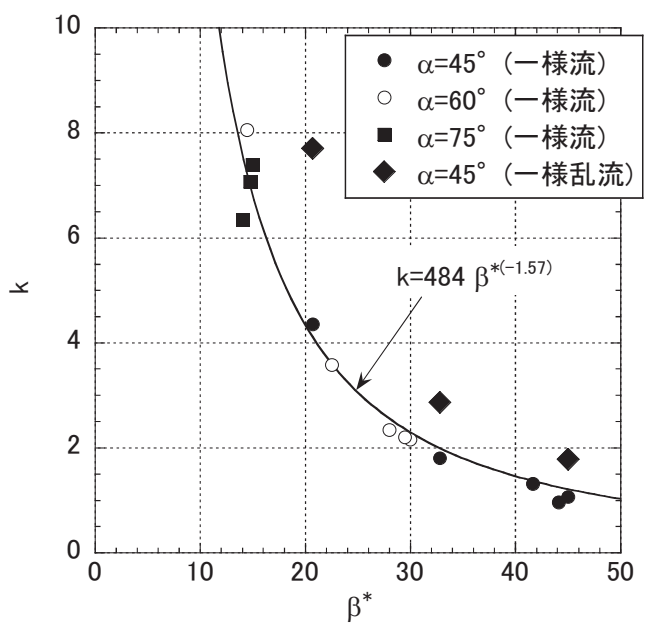

図 17 ココヒーレンスの減衰係数 $k$

\section{4. 結論}

本研究は，傾斜円柱に作用する風力特性における傾斜角及び迎角 の影響について検討を行ったものである．本研究では，マニホール ドを用いて傾斜円柱全体の層風力を同時測定し，層風力の部材軸方 向分布特性及び鋼管鉄塔部材を想定した一般化風力特性について検 討した．本研究により傾斜円柱に作用する風力特性として以下のこ とが明らかとなった。

1. 風方向及び風直交方向の一般化風力係数及び一般化風力のパ ワースペクトル密度より求めたストローハル数は, 余弦則に従 い, 風向に対する傾斜円柱の角度である等価迎角の余弦関数に よって表すことができる.

2. 風直交方向変動風力は, 風上側から風下側に向かって一定速度 で伝搬しており，この伝搬速度は等価迎角の一次関数で表すこ とが出来る。また，風直交方向風力の部材方向相関は，渦放出 周波数付近において非常に高い相関を示す.

3. 一様流と乱れ強さ $5 \%$, 乱れのスケールが模型直径の $1 \sim 2$ 倍の 一様乱流を用いた実験を行ったが，これらの気流中では傾斜円 柱に作用寸る風力特性に大きな差は見られなかった。

なお，本研究の実験は模型の端部に床と天井のある状況で行った ものであり，実際の鋼管鉄塔の斜材とは端部条件が異なっている. 今後，端部条件による風力特性の変化について検討を行う必要があ る.

\section{参考文献}

1) 淡嶋毅弘，大熊武司，本郷榮次郎，漆原秀雄，丸川比佐夫，岡村俊良，鋼 管トラス鉄塔における腹材の風応答に関する実測, 日本建築学会大会学術 講演梗概集(北海道)B-1 分冊, pp.137-138, 2004

2) 花田敦也，薄達哉，本間真，大森睦，前田潤滋，鉄塔支持型煙突における 鉄塔構成部材の風応答特性(その 1 ), 日本建築学会大会学術講演梗概集(北 海道) B-1 分冊, pp.145-146, 2004

3) Ramberg, S.E., The effects of yaw and finite length upon the vortex wakes of stationary and vibrating circular cylinders, Journal of Fluid Mechanics, vol. 128, pp.81-107, 1983

4) 松本勝, 白石成人, 北沢正彦, 辻井正人, 平井滋登, 傾斜円柱の空力振動 
特性ーケーブル Rain Vibration との関連性一, 第 10 回風工学シンポジウム, pp.139-144, 1988

5) 林農, 吉野章男, 若良二, 河村哲也, 傾斜円柱の表面圧力分布について(円 柱軸方向風圧分布へのエンドプレートの影響), 日本機械学会論文集(B 編), 58 巻 545 号, pp.71-78, 1992

6) 河村哲也, 林農, 傾斜円柱周りの流れの数值解析, 日本機械学会論文集(B 編)， 58 巻 548 号, pp.89-96, 1992-4

7) 松本勝, 八木知己, 對馬大輔, 後藤光理, 酒井精一郎, 斜長橋ケーブルに おける軸方向渦と高風速渦励振に関する基礎的研究, 第 16 回風工学シンポ ジウム, pp.501-506, 2000

8) Zdravkovich, M.M., Flow around circular cylinders vol2 Chap.25, Oxford Science Publication, 2003

9) Yeo, D.H., Nicholas P., Investigation on 3-D characteristics of flow around a yawed and inclined circular cylinder, Journal of Wind Engineering and Industrial Aerodynamics, vol.96, pp.1947-1960, 2008

10) Cheng, S., Larose, G.L., Savage, M.G., Tanaka, H., Irwin, P.A., Experimental study on the wind-induced vibration of a dry inclined cable - Part I: Phenomena, Journal of Wind Engineering and Industrial Aerodynamics, vol.96, pp.2231-2253, 2008

11) Cheng, S., Irwin, P.A., Tanaka. H., Experimental study on the wind-induced vibration of a dry inclined cable - Part II: Proposed mechanisms, Journal of Wind Engineering and Industrial Aerodynamics, vol.96, pp.2254-2272, 2008
12）鶴見俊雄, 大熊武司, 片桐純治, 丸川比佐夫, 迎角を有する円形断面部 材に作用する風直角方向風力特性に関する研究, 日本建築学会大会学術講 演梗概集(東海) B-1 分冊, pp.181-182，2003

13) 片桐純治, 大熊武司, 鶴見俊雄, 丸川比佐夫, 傾斜円柱の風直角方向風 応答性状に関する研究, 日本建築学会大会学術講演梗概集(北海道) B-1 分冊, pp.135-136, 2004

14) 漆原秀雄, 大熊武司, 本郷榮次郎, 丸川比佐夫, 片桐純治, 岡村俊良, 鉄塔腹材の後流渦励振に関する風力特性に関する研究 その 3 腹材の弱軸 方向の応答予測, 日本建築学会大会学術講演梗概集(北海道) B-1 分冊, pp.143-144, 2004

15) Gumly, S.J., Tubing systems for pneumatic averaging of fluctuating pressures, Journal of Industrial Aerodynamics, vol.12, pp.189-228, 1983

16) 片桐純治, 鶴見俊雄, 大熊武司, 丸川比佐夫, 迎角を有寸る傾斜円柱に 作用する風力特性に関する研究 その 1 実験方法及び一般化風力係数, 日 本建築学会大会学術講演梗概集(東北) B-1 分冊, pp.181-182, 2009

17) 鶴見俊雄, 片桐純治, 大熊武司, 丸川比佐夫, 迎角を有する傾斜円柱に 作用する風力特性に関する研究 その 2 風軸直交方向風力のスペクトル特 性及び部材軸方向位相特性, 日本建築学会大会学術講演梗概集(東北) B-1 分冊, pp.183-184, 2009

(2009年 6 月16日原稿受理, 2009年 9 月 8 日採用決定) 